122 seerna att begrunda och motivera sina förvärv för publiken? Vilken människouppfattning eller uppfattning om samhället står bakom utställningspolitiken och utställningsplaneringen?

Det är sådana och motsvarande frågor som Anne Aurasmaas bok enligt min mening vill väcka - väcka medvetande om frågan om museets väsen - även om författaren själv arbetar på en lärd bas utan att provocera annat än de små grå hjärncellerna att jobba något livligare.

Annika Waenerberg professor i konsthistoria, Jyväskylä

\section{Framtidens rötter}

Hugues de Varine, Les Racines du Futur. Le patrimoine au service du développement local. Collection Decision locale. Asdic 2002. ISBN 29509506-6-3.

Ännu inte 30-årig knöts Hugues de Varine 1962 till ICOMs sekretariat i Paris som medarbetare till den samtida franska museologins huvudperson Georges Henri Rivière (18971985). Han efterträdde Rivière som organisationens direktör 1964 och arbetade målmedvetet för ICOMs - och museernas - förnyelse under den följande tioårsperioden. Museerna måste demokratiseras och öppnas mot samhället, tredje världens museer ta en aktiv del i social och kulturell utveckling. Förnyelsen drevs fram under en följd av ICOMs generalkonferenser och andra internationella möten. Han medverkade vid tillkomsten av ICOMOS 1965 och han uppfann ordet 'ekomuseum' 1971 (generalkonferensen i Grenoble), vilket han tillsammans med Rivière bidrog till att ge ett innehåll. Särskilt gjordes detta utifrån erfarenheterna med det 'klassiska' Le Creusotmuseet. Hur intryck från hans världsvida resande i ICOMs tjänst påverkat hans tänkande och museisyn redovisade han - sedan han 1974 lämnat ICOM - i boken La Culture des Autres (De andras kultur). Kulturen, skriver han, är fortfarande en livsform i ett oräkneligt antal samhällen, men i västvärlden har den blivit en konsumtionsprodukt och handelsvara som hotar att kväva de livsformer som inte underordnar sig kommersialismens och konsumismens imperativ. Han pläderar för en kulturell frigörelse grundad på enskilda människors och samhällens initiativ och för en interkulturell dialog grundad på ömsesidig respekt. Redan 1969 har han skrivit en uppsats Le musée au service de l'homme et du développement (Museet i människans och utvecklingens tjänst) - som emellertid kom att publiceras först många år senare - där han otåligt förklarar det traditionella museet (som historisk produkt av nostalgi och snobberi) överspelat och dömt att försvinna. Ekomuseet står under de följande åren i centrum för hans intresse när han en period arbetar vid kulturdepartementet och senare - efter ett mellanspel i Portugal som ledare för Institut Francais i Lissabon - vid socialdepartementet. Men redan tidigt skriver han: Ekomuseet är i första hand ett samhälle och har ett mål - detta samhälles utveckling. Han deltar i bildandet av MINOM (Mouvement international pour une nouvelle muséologie) 1985 i Lissabon och framträder följande år vid MINOMs möte i norska Toten. I den publikation, Ökomuseumsboka, som blir resultatet finns inte mindre än fem texter av Hugues de Varine som speglar hur hans tänkande nu utvecklats mot det begrepp, musée communautaire (samhällsmuseum), som fylligt beskrivs i boken L'initiative communau- 
taire, recherche et expérimentation, 1991 (också på portugisiska med titeln $O$ tempo social, utgiven i Brasilien 1987). Det kan för övrigt även följas i de åter- och framåtblickande uppsatser av hans hand som publicerats i Nordisk Museologi (1994/1 och 2).

Hugues de Varine är, som John Aage Gjestrum skriver i Ökomuseumsboka 1988, en av de enskilda personer som starkast präglat museiutvecklingen under 1970- och 80-talen. Han fortsatte under 1990-talet att gästspela i ICOM, exempelvis vid generalkonferensen i Québec 1993, arbetade med konsultuppdrag för Unesco och Europarådet, men har alltmer ägnat sig åt utvecklingsprojekt, inte minst i olika delar av Frankrike. Hans betydelse är fortfarande påtaglig genom den internationella verksamheten, genom de nätverk han byggt upp, föredrag och författarskap.

När han 40 år efter sin entré i museivärlden utkommer med en ny bok ligger det nära till hands att se den som en slutsummering av hur han uppfattar kulturarvets samhällsroll och betydelse för människor på väg mot framtiden. Han snabbtecknar i en introduktion hur yrkeskarriären förändrat hans kultursyn och fastslår att "kulturarvet politiskt är ett utvecklingskapital och en central del av det kollektiva medvetandet”. I sex kapitel behandlar han därefter i tur och ordning

- kunskapen om kulturarvet: ett samhälles arvsmassa, dess DNA

- användningen (les usages) av kulturarvet

- organisationen av kulturarvsutvecklingen

(l'action patrimoniale)

- politiska utvecklingsstrategier

- museet som instrument för utvecklingen

- kulturarvsutvecklingens ekonomi

Han håller fast vid sin optimistiska syn på människors drift och förmåga att förändra och utveckla sin livskvalitet, på att den kulturmiljö de lever i alltid bär på löften och utvecklings123 möjligheter, på att den kan förbättras med enskilda initiativ. Det är nuets människor som måste aktivt leva en kultur. Men bygdeutvecklingens problem är att den analyseras utifrån och från utgångspunkter - ekonomiska, sociala, kulturella - som inte ses i samband med varandra utan separata. De berörda människornas inifrånperspektiv beaktas inte, ges inte utrymme, trots att deras förfoganderätt över de lokala villkoren borde ge dem initiativrätten. Kulturarvet är grogrunden, ger ramarna och resurserna för utveckling. Kulturarvet är tidsbundet - det har ett förflutet, ett nu och en framtid. Det är också dynamiskt, ovillkorligen underkastat förändringar och över dem kan bara kulturbärarna själva råda. Allt detta utvecklas i de sex kapitlen med rika exempel från projekt runt om i världen.

Han är påtagligt misstänksam mot att överlämna ansvaret för kulturen till institutioner och byråkratiska strukturer. Förvånande är att han inte riktigt tror på den förändring av museers arbete som han kämpat för, inte heller på att de spontana museala initiativ som tagits av grupper och samhällen inspirerade av den nya museologin kan få någon större livslängd - de kan vara livsuppehållande under en eldsjälsgeneration för att sedan slockna eller innebära en ekonomisk överbelastning för sitt samhälle. Det finns i det näst sista kapitlets tillbakablick på de fyrtio årens museiutveckling en sorgsen underton över det ideella företagets fåfänglighet som på något sätt strider mot bokens energiska program för bygdeutveckling.

Han skriver enkelt och klart och med en 'fransk' vilja till pedagogisk klarhet som visar sig i att varje kapitel avslutas med praktiska råd (fiche pratique) om hur innehållet kan tillämpas och bearbetas i konkreta fall. (PUA) 